\section{First seven years of a new NHS mental handicap service 1974-81}

SIR,-In her account of her experiences with a community unit in the style put forward by the late National Development Group for the mentally handicapped (24 July, p 269), Dr A Mary Myers points out that her service has been developed to meet local needs. She makes the significant comment that it has been impossible to identify any philosophy or local authority residential plan for the mentally handicapped in Rotherham since 1974.

The document Better Services, referred to by $\mathrm{Dr}$ Myers, indicates that the Rotherham local authority should provide about 185 adult and 30 children's residential places. To what degree has her NHS initiative been promoted to plug this gap? Is there special reliance in South Yorkshire on central government funding through the Health Service of what might be regarded elsewhere as essentially social provisions?

Apparently in Rotherham and Sheffield there is no difference in dependency between hospital hostel patients (who occupy $50 \%$ of the local hospital beds) and local authority hostel residents. Dr Myers does, however, mention that there are also $\mathbf{1 0 0}$ Rotherham patients in mental handicap hospitals outwith the district; there may be others in general psychiatric facilities, prisons, or the probation services.

According to the 1980 report of the National Development Team, $35 \%$ of adults in mental handicap hospitals require continuing NHS specialist services. Their figures suggest 135 beds in Rotherham for these purposes, for which they give clinical guidelines. They are less clear, however, about community units, whose NHS functions are arguable.

Although many of these planning figures are suspect, it is true that the majority of the mentally handicapped do not require specialist doctors, nurses, or services delivered through a health service; perhaps Dr Myers gives us a clue by using the terms "clients" or "residents" in her article over twice as frequently as "patients."

T I PILkINGToN

Whixley Hospital

\section{Birth asphyxia}

SIR,-In his leading article on birth asphyxia (1 May, p 1288) Dr D P Addy attempted, successfully in our opinion, to show how clinical assessment could be used to predict the consequences of birth asphyxia. Thus we do not share the critical attitude to this article held by Dr G S Sykes and others (24 July, p 289). In their letter Dr Sykes and his colleagues claim that the measurement of umbilical cord $\mathrm{pH}$ and base excess is a useful guide to the success of the obstetric management of labour. Neonatal and obstetric care must ultimately be measured in terms of perinatal mortality and morbidity in survivors. They may be right in supposing that cord blood measurements might provide more reliable prognostic indications than do Apgar scores but there is no evidence to support this view. Indeed, as Sykes and his colleagues conclude in their paper, ${ }^{1}$ a large longitudinal study is required.

Both Dr Addy and Dr Sykes and others might have drawn attention to the possibility that clinical assessment of the baby apnoeic at one minute may be more usefully made on the basis of a division into "primary" or "terminal" apnoea rather than by the Apgar score. ${ }^{2}$ Again this clinical assessment, routinely (but not invariably) carried out by paediatricians at the John Radcliffe Hospital and many other hospitals, needs to be related both to the acid-base status of cord blood and to longterm prognosis.

In apnoeic newborn babies in terminal apnoea the most useful guide to prognosis in terms of survival and survival without brain damage lies in the time taken to the onset of spontaneous breathing. Scott ${ }^{3}$ and Steiner and Neligan ${ }^{4}$ were the first to show a relation between the time to the onset of regular respiration and subsequent cerebral palsy. Cerebral palsy was not found at follow-up in either of these studies in babies who responded to resuscitation by the onset of regular respirations by $20-30$ minutes. In those babies who failed to establish regular respirations by 20-30 minutes after birth the incidence of cerebral palsy was high. These findings have been supported by Mulligan et al, ${ }^{5}$ reporting on the outcome of 13000 deliveries, and by the report of the American National Collaborative Perinatal Project. ${ }^{6}$ This report on the long-term follow-up of 49000 deliveries found that babies with one-minute Apgar scores of 0-3 who responded to resuscitation and had Apgar scores of greater than 3 at 15 minutes had an incidence of cerebral palsy in survivors of less than $10 \%$. In babies with an Apgar score persisting at or below 3 at 20 minutes the rate of cerebral palsy among survivors was no less than $57 \%$.

A relationship has therefore been shown between the clinical assessment of the response to resuscitation of a newborn in terminal apnoea and subsequent morbidity. Such a relationship will have to be shown for cord blood $\mathrm{pH}$ before it can be considered a necessary aspect of the assessment of obstetric management or as an adequate discriminator of the newborn at risk of cerebral palsy. Even if cord blood $\mathrm{pH}$ is shown to provide useful indications of survival and prognosis the paediatrician will, rightly, continue to be guided by clinical observations in making decisions about the necessity for and the extent of resuscitation procedures.

JANET A EYRE ANDREW R WILKINSON PETer TIZard

Department of Paediatrics, John Radcliffe Hospital
Oxford OX3 9DU 1 Sykes GS, Molloy PM, Johnson P, Gu W, Ashworth
F, Stirratt GM, Turnbull AC. Lancet 1982;i: 494-6.
${ }^{2}$ Gupta JM, Tizard JPM Lancet $1967 ;$;i $55-9$. ${ }^{2}$ Gupta JM, Tizard JPM. Lancet 1967; ;i :

- Steiner H, Neligan G. Arch Dis Child 1975;50:696-70. Mulligan JC, Painter MW, O'Donoghue P, MacDonald HM, Allen AC, Taylor PM. J Pediatr 1980; 96:903-7.

- Nelson KB, Ellenberg JH. Pediatrics 1981 ;68:36-44.

\section{Genitourinary medicine}

SIR,-Your correspondence from $\mathrm{Mr} S \mathrm{D}$ Ford (3 July, p 62) and Mr M N Bhattacharyya (24 July, p 291) concerning Professor $M$ W Adler's article (5 June, p 1677) would seem to suggest that genitourinary physicians are concerned with only one aspect of their patients' health. This could not be further from the truth: genitourinary physicians practise whole-patient medicine more frequently than other colleagues, and there is no place in the specialty for the consultant who does not. Indeed, one is often frustrated by the general practitioner colleague who either omits the courtesy of a referral letter or who omits relevant details of the patient's past medical, family, or social history.

Certainly one feels uneasy about not informing the patient's family doctor that one is treating his patient, but many patients of special clinics express a desire that their usual medical advisers should not know of their attendances. Nevertheless, should the general practitioner refer a patient (with or without a letter) it is my invariable practice to attempt to reply within the week, as does $\mathrm{Dr}$ Bhattacharyya. In addition, if the patient has a potentially dangerous long-term condition and has not been referred by the GP, I always ask for the patient's permission to contact him-most patients in such circumstances acquiesce.

We will not be successful in controlling the sexually transmitted diseases or in providing a good genitourinary consultant service without close and respectful co-operation between the hospital specialists and their GP colleagues. We attempt very much in South Yorkshire to foster this dialogue and indeed have recently held an update for general practitioners on sexually transmitted diseases. We would, of course, be most delighted to send Dr Ford or any of his partners details of our next course.

Martin Talbot

Department of Genitourinary Medicine, Royal Infirmary,

***This correspondence is now closed.-ED, BMF.

\section{Sphygmomanometers in hospital and family practice}

SIR,-On the day that $\mathrm{Mr} M \mathrm{~J}$ Burke and others (14 August, p 469) reminded us to use a long inflatable bladder to measure blood pressure 12 major surgical suppliers were asked if they stocked the recommended cuff, size $35.4 \mathrm{~cm} \times 12.7 \mathrm{~cm}(14 \mathrm{in} \times 5 \mathrm{in})$. Only one of the suppliers questioned stocked the cuff, most being unaware of its existence. These authors published their recommendations in a series in the $B M Y$ in 1979 , later collected together into the $A B C$ of Hypertension. ${ }^{1}$ In the ensuing years had the demand for these cuffs been so slight that most suppliers have never heard of them ? Do we need an even more authoritative body to make its recommendation on this universal and cheap piece of equipment ? Perhaps the most persuasive argument in favour of the long $35-\mathrm{cm}$ cuff is that it is much easier to use than the standard $23-\mathrm{cm}$ cuff in common use, both in hospital and family practice.

Northallerton

T J THORNTON

1 O'Brien ET, O'Malley K. In: $A B C$ of hypertension. London: BMA, 1980.

SIR,-I read the report from the blood pressure measurement laboratory, Dublin, with interest (14 August, p 469). However, the authors do not state whether the sphygmomanometers they tested were in current use; neither do they state why a gauge error of $\pm 4 \mathrm{~mm} \mathrm{Hg}$ was an acceptable test criterion. 